\title{
Perbedaan Dan Pengaruh Indikator Ketahanan Pangan Terhadap Proporsi BBLR Pada Wilayah Pesisir Pulau Jawa (Kabupaten Bangkalan dan Kabupaten Tulungagung)
}

\section{Differences and Influence In Food Security Indicators of Low Birth Weight Proportion On Coastal Areas In Java Island (Kabupaten Bangkalan and Kabupaten Tulungagung)}

\author{
Qurrota A'yun Febrina Triwindiyanti ${ }^{{ }^{1}}$, Edy Purwanto Tertius ${ }^{2}$, Trias Mahmudiono ${ }^{1}$
}

\begin{abstract}
ABSTRAK
Latar Belakang: Pangan dan produksi pangan berkaitan dengan ketahanan pangan dan status gizi suatu wilayah. Terdapat 9 indikator ketahanan pangan yaitu rasio warung, rasio toko, rasio rumah tangga tidak sejahtera, rasio rumah tangga tanpa arus listrik, rasio akses roda 4, rasio anak tidak sekolah, rasio rumah tangga tanpa air bersih, rasio jumlah tenaga kesehatan, dan rasio fasilitas sanitasi. Ketahanan pangan dipengaruhi beberapa aspek, selain aspek ketersediaan, angka kemiskinan tiap tahun juga mempengaruhi status ketahanan pangan. Rumah tangga di wilayah pesisir memiliki tingkat kesejahteraan rendah, hal ini disebabkan adanya pembagian hasil tangkap yang kecil pada nelayan. Berdasarkan Food Security Vulnerability Atlas (FSVA) tahun 2016 wilayah Kabupaten Bangkalan dan Kabupaten Tulungagung termasuk dalam kategori wilayah rawan pangan, serta masih ditemukan adanya BBLR kedua Kabupaten.

Tujuan: Untuk menganalisis perbedaan serta pengaruh antara indikator ketahanan pangan pada aspek ketersediaan dengan proporsi BBLR pada wilayah pesisir laut utara dan laut selatan provinsi Jawa Timur.

Metode: Penelitian ini menganalisis data sekunder yang diperoleh dari Dinas Pertanian dan Ketahanan Pangan Provinsi Jawa Timur serta Dinas Kesehatan Kabupaten Bangkalan dan Kabupaten Tulungagung. Analisis pengaruh menggunakan Uji Regresi liner dan uji perbedaan menggunakan uji-t independent.

Hasil: Analisis uji beda didapatkan hasil yaitu pada variabel rasio toko $(0,994)$, rasio anak tidak sekolah $(0,084)$, rasio jumlah tenaga kesehatan $(0,137)$, dan rasio fasilitas sanitasi $(0,959)$.

Kesimpulan: Dari hasil uji pengaruh tidak terdapat pengaruh dari indikator ketahanan pangan yang meliputi rasio warung, rasio toko, rasio rumah tangga tidak sejahtera, rasio rumah tangga tanpa arus listrik, rasio akses roda 4, rasio anak tidak sekolah, rasio rumah tangga tanpa air bersih, rasio jumlah tenaga kesehatan, dan rasio fasilitas sanitasi dengan proporsi BBLR di Kabupaten Bangkalan dan Tulungagung. Hasil uji beda dari Kabupaten Bangkalan dan Kabupaten Tulungagung terdapat perbedaan pada variabel rasio toko, anak tidak sekolah, jumlah nakes dan fasilitas sanitasi.
\end{abstract}

Kata Kunci: ketahanan pangan, proporsi BBLR, wilayah pesisir 


\begin{abstract}
Background: Food and food production is closely related to food security and nutritional status of a region. There are 9 indicators of food security: stall ratios, store ratios, non-prosperous household ratios, household no-electric ratio, four-wheel access ratios, non-school-age ratio, net open water ratio, ratio of health personnel, and facility ratio sanitation. In addition to availability, the annual poverty rate declines, but is different from that of coastal households. Households in coastal areas have low levels of welfare, this is due to the small share of fish catches to fishermen. Based on Food Security Vulnerability Atlas (FSVA) in 2016, Kabupaten Bangkalan and Tulungagung are categorized as food insecurity areas.

Objective: To analyze the difference between food security indicator with nutritional status (proportion of LBW) in west coastal and south coastal area of East Java Province.

Method: This research is by analyzing secondary data obtained from Dinas Pertanian dan Ketahanan Pangan Jawa Timur and Dinas Kesehatan of Kabupaten Bangkalan and Tulungagung. Analysis of influence using linear regression test and difference test using independent $t$-test.

Result: The test result of independent $t$-test were found on store ratio variable (0.994), non-school ratio (0.084), ratio of nakes (0.137), and ratio of sanitation facility (0.959).

Conclusion: From the result of the influence test, there is no effect from food security indicator which include the ratio of shop, store ratio, non-prosperous ratio, non electric rt ratio, 4 wheel access ratio, and ratio of sanitation facilities with LBW in Bangkalan and Tulungagung districts. Independent $t$-test have differences in store ratios, non-school variables, number of nakes and sanitation facilities.
\end{abstract}

Keywords: food security, proportion of $L B W$, coastal areas

\footnotetext{
*Koresponden:

qurrotaayunfebrina@gmail.com

${ }^{1}$ Departemen Gizi Kesehatan

Fakultas Kesehatan Masyarakat, Universitas Airlangga

${ }^{2}$ Dinas Kesehatan Provinsi Jawa Timur
}

\section{PENDAHULUAN}

Pengertian pangan dalam Peraturan Pemerintah Republik Indonesia No 28 Tahun 2004 bahan dari sumber hayati serta air, baik melalui proses pengolahan maupun tidak melalui proses pengolahan. Proses pengolahan yang dilakukan untuk konsumsi manusia sebagai makanan atau minuman. Ketahanan pangan merujuk pada UU Nomor 18 Tahun 2012 menjelaskan bahwa kondisi terpenuhinya pangan suatu wilayah dari lingkung mikro (perorangan) yang tergambar dari jumlah dan mutu pangan yang terpenuhi, aman, beragam dan bergizi serta sesuai dengan ketentuan agama, keyakinan dan budaya. Pencegahan kerentanan dalam kerawanan pangan dan gizi wilayah perlu adanya program peningkatan status ketahanan pangan dan gizi individu suatu wilayah.

Kerawanan pangan dan gizi merupakan masalah yang kompleks, analisis kerawanan pangan mencakup pada beberapa parameter tidak hanya parameter cakupan produksi pangan saja. Kondisi rawan pangan merupakan cerminan ketidakmampuan suatu daerah untuk memenuhi pangan yang cukup untuk dapat hidup sehat serta produktif dalam waktu sementara maupun waktu yang lama. Kerawanan pangan wilayah dapat diukur dari banyaknya rumah tangga pra sejahtera dengan alasan status ekonomi, status gizi masyarakat dari jumlah status gizi balita, serta 
ketersediaan pangan dan kerentanan pangan suatu daerah ${ }^{1}$.

Suatu wilayah memiliki status tahan pangan dapat diukur dari aspek ketersediaan pangan. Terpenuhinya ketersediaan pangan dilihat dari beberapa indikator hasil pemetaan ketahanan dan kerentanan pangan terhadap kerawanan pangan suatu wilayah. Ketersediaan pangan memiliki 9 indikator rawan pangan yang terdiri dari indikator rasio warung, rasio toko, rasio keluarga tidak sejahtera, rasio rumah tangga tanpa listrik, rasio akses roda 4, rasio anak tidak sekolah, rasio rumah tangga tanpa air bersih, rasio jumlah tenaga kesehatan dan rasio fasilitas sanitasi ${ }^{2}$. Status gizi seseorang secara tidak langsung dipengaruhi oleh ketersediaan pangan individu. Aspek akses pangan dan akses pemanfaatan mempengaruhi status ketahanan pangan ${ }^{3}$. Tingkat kemiskinan suatu wilayah mempengaruhi juga untuk akses pangannya ${ }^{4}$. Ketersediaan pangan disuatu daerah haruslah sejalan dengan akses pangan didaerah tersebut, namun jika hal tersebut tidak sejalan maka akan berdampak pada penyerapan pangan yang kurang maksimal sehingga wilayah tersebut masih tergolong dalam wilayah rawan pangan ${ }^{3}$.

Penurunan tingkat kemiskinan penduduk Jawa Timur terjadi pada Bulan September 2016 yaitu sebesar 11,85\% yang turun dari $9,75 \%$ yang dimana presentasenya di Bulan Maret 2016 sebesar 12,05\% ${ }^{4}$. Tingkat penurunan kemiskinan yang terjadi di Provinsi Jawa Timur ternyata belum mampu menurunkan angka kerawanan pangan yang masih terjadi dibeberapa Kabupaten di Jawa Timur. Penyebabnya yaitu masih tinggi harga yang harus dibayarkan untuk memenuhi kebutuhan pangan. Data hasil Susenas untuk periode Maret hingga September 2016 menunjukkan adanya kenaikan sebesar 2,30\%. Hasil tangkap ikan yang didapat nelayan belum dapat mecerminkan kesejahteraan ekonomi nelayan. Provinsi Jawa Timur pada tahun 2008 merupakan provinsi dengan jumlah hasil tangkap ikan laut terbesar yaitu \pm 394.000 ton. Pada Provinsi Jawa Timur khususnya wilayah pantai utara pulau Jawa memiliki hasil tangkap ikan sebesar 274.012.994 kg/tahun ${ }^{5}$.
Indonesia merupakan negara maritim dengan luas wilayah perairannya mencapai 75\% dari daratan, hal ini menjadikan bidang perikanan mempunyai peranan yang penting pada rencana pembangunan. Pembangunan pada sektor perikanan terutama perikanan tangkap tujuannya untuk meningkatkan kesejahteraan masyarakat khususnya nelayan. Setiap wilayah mempunyai karakteristik geografis yang berbeda, hal ini menjadikan suatu wilayah memiliki kemampuan sumberdaya alam yang berbeda ${ }^{6}$.

Tanjung bumi merupakan salah satu kecamatan di Kabupaten Bangkalan yang berada di pesisir utara. Pada hasil kajian Suhartono tahun 2010 di wilayah pesisir utara laut Jawa khususnya wilayah Bangkalan Kecamatan Tanjung Bumi mengalami kerawanan pangan dengan faktor penyebabnya adalah indikator konsumsi normatif, jumlah penduduk miskin, penduduk buta huruf, akses air bersih yang rendah, serta keterbatasan akses listrik ${ }^{7}$. Kabupaten Bangkalan dan kabupaten Tulungagung merupakan kabupaten dengan kecamatan yang memiliki status ketahanan pangan pada prioritas 1 dan prioritas 2. Pada Kabupaten Bangkalan status ketahanan pangan rumah tangga masuk pada status prioritas 1 . Status prioritas 1 yaitu jumlah desa dan persentase desa sangat rawan terhadap kerentanan pangan per Kabupaten ${ }^{2}$. Hal ini berbeda pada Kabupaten Tulungagung, ketahanan rumah tangga di Kabupaten Tulungagung termasuk dalam prioritas 2 dengan kondisi rentan terhadap kerawanan pangan.

Status kerawanan pangan wilayah yang berbeda antara pesisir utara Jawa dan pesisir selatan Jawa akankah berpengaruh terhadap status gizi individu. Tujuan dari penelitian ini yaitu untuk melihat apakah ada perbedaan indikator ketahanan pangan pada aspek ketersediaan serta pengaruh antar indikator terhadap proporsi BBLR pada wilayah pesisir laut utara (Bangkalan) dan laut selatan (Tulungagung) provinsi Jawa Timur

\section{METODE}

Penelitian ini dilakukan pada Kabupaten Bangkalan meliputi jumlah 18 kecamatan 
serta pada Kabupaten Tulungagung sebanyak 19 kecamatan. Data yang digunakan pada penelitian yaitu menggunakan jenis data sekunder Food Security Vulnerability Atlas (FSVA) yang didapatkan di Dinas Pertanian dan Ketahanan Pangan Provinsi Jawa Timur serta Badan Statistik Kabupaten. Penelitian ini dilakukan pada Kabupaten Bangkalan dan Kabupaten Tulungagung karena Kabupaten Bangkalan merupakan wilayah pesisir utara Provinsi Jawa Timur dan Kabupaten Tulungagung yang merupakan wilayah pesisir selatan Provinsi Jawa Timur. Data sekunder FSVA, Indikator ketahaan pangan pada aspek ketersediaan yang digunakan yaitu Rasio warung, Rasio toko, Rasio non sejahtera, Rasio Rumah Tangga non listrik, Rasio akses roda 4, Rasio anak tidak sekolah, Rasio RT tanpa air bersih, Rasio tenaga kesehatan, Rasio fasilitas sanitasi

Data rawan pangan merupakan data sekunder dari laporan tahunan periode tahun 2013, 2014, dan 2015 yang dilaporkan pada tahun 2016 oleh Dinas Pertanian dan Ketahanan Pangan Provinsi Jawa Timur. Data sekunder Kabupaten merupakan data Porfil Kesehatan Tahun 2015 terutama pada proporsi BBLR. Uji statistik yang digunakan adalah uji regresi linier dan uji t-test. Regresi linier digunakan untuk mengetahui apakah ada pengaruh dari indikator terhadap proposi BBLR serta t-test digunakan untuk mengetahui perbedaan 9 indikator kerawanan pangan dengan proporsi BBLR antara kedua Kabupaten.

\section{HASIL DAN PEMBAHASAN}

Penelitian ini menggunakan data sekunder yang berasal dari Dinas Pertanian dan Ketahanan Pangan berdasarkan Food Security Vulnerability Atlas (FSVA). FSVA tahun 2016 menunjukkan bahwa Kabupaten rawan pangan dengan persentase 2,85\% adalah Kabupaten Bangkalan. Bangkalan merupakan kabupaten dengan urutan ke-4 daerah paling rawan pangan setelah Kabupaten Bondowoso, Sumenep, dan Probolinggo di Provinsi Jawa Timur. Kabupaten Bangkalan memiliki beberapa Kecamatan yang menjadi prioritas utama kerawanan pangan, kecamatan tersebut merupakan kecamatan yang berada di daerah pesisir Bangkalan meliputi Kecamatan Klampis, Kecamatan Kokop, Kecamatan Konang, Kecamatan Kwanyar, Kecamatan Sepulu, serta Kecamatan Tanjung bumi².

Desa di Kabupaten Tulungagung masuk dalam kategori wilayah rentan terhadap kerawanan pangan 2,2\%. Status ketahanan pangan pada Kabupaten Tulungagung serupa dengan Kabupaten Bangkalan yaitu mayoritas kecamatan yang mengalami rentan rawan pangan merupakan kecamatan pada wilayah pesisir. Kecamatan yang masuk pada wilayah pesisir, yaitu pada Kecamatan Campurdarat, dan Kecamatan Pucanglaban ${ }^{8}$. Ketahanan pangan rumah tangga memiliki penyebab utama yaitu pada faktor ketersediaan serta faktor utama penyebab terjadin kerawanan pangan yaitu faktor sosial dan ekonomi ${ }^{8}$.

Data kesehatan diperoleh berdasarkan data sekunder dari Dinas Kesehatan Kabupaten pada tahun 2015. Berdasarkan data bahwa ditemukan kasus BBLR yang paling banyak di Kabupaten Bangkalan adalah di daerah pesisir yaitu Kecamatan Galis, Kecamatan Socah dan Kecamatan Tanjung Bumi ${ }^{9}$. Sedangkan di Kabupaten Tulungagung kasus BBLR tertinggi ditemukan pula didaerah pesisir yaitu pada Kecamatan Bandung, Kecamatan Rejotangan, Kecamatan Boyolangu, Kecamatan Kedungwaru, Kecamatn Ngantru, Kecamatan Gondang dan Kecamatan Sendang ${ }^{10}$.

Proporsi BBLR pada wilayah rawan pangan dapat diketahui pengaruh indikatornya dengan menggunakan uji regresi linier sederhana. Hasil menunjukkan lebih dari $\alpha$ 0,005 dan berarti tidak memiliki pengaruh terhadap setiap indikator terhadap proporsi BBLR. Tidak ada pengaruh terhadap proporsi kejadian BBLR di dua Kabupaten Provinsi Jawa Timur berdasarkan indikator ketersediaan dari ketahanan pangan di wilayah tersebut. Penambahan berat badan ibu hamil, KEK, anemia, jarak kehamilan, dan jarak kehamilan dapat mempengaruhi terjadinya $\mathrm{BBLR}^{11}$. Kondisi Fisiologi pada ibu hamil yang tidak baik dan atau sedang dalam keadaan menderita suatu penyakit dapat mengakibatkan BBLR terjadi. Salah satu 
parameter kesehatan masyarakat dan erat kaitannya dengan angka kesakitan, kurang gizi dan kematian adalah Angka BBLR.

Indikator ketahanan pangan rumah tangga tidak berpengaruh terhadap proporsi BBLR karena merupakan faktor tidak langsung. Faktor langsung yang mempengaruhi yaitu faktor fisiologis ibu dan janin. Faktor fisiologis ibu terdiri dari status gizi serta riwayat kehamilan $^{12}$. Kejadian BBLR salah satunya disebabkan oleh status gizi rendah pada ibu hamil ${ }^{13}$. Status gizi dipengaruhi oleh pendapatan/faktor ekonomi, seseorang dengan pendapatan dibawah rata-rata memiliki resiko lebih besar mengalami status gizi yng rendah dibandingkan dengan individu yang memiliki pendapatan lebih atau sama dengan normal. Individu dengan ekonomi rendah merupakan faktor penyebab dari ketersediaan rumah tangga, apabila ketersediaan kurang maka indvidu tersebut tidak tahan pangan ${ }^{14}$.

Faktor ekonomi dan ketahanan pangan memiliki hubungan dengan kejadian BBLR disuatu wilayah. Apabila rumah tangga dalam keadaan tidak tahan pangan atau status ekonomi rendah dapat memberikan dampak pada konsumsi individu per anggota keluarga ${ }^{15}$.

Uji perbedaan antara wilayah rawan pangan terhadap proporsi BBLR di Kabupaten Bangkalan dan Kabupaten Tulungagung dilakukan untuk melihat adakah perbedaan setiap variabel pada dua kabupaten. Perbedaan dengan uji t dijelaskan pada Tabel 2. Tabel 2 mengambarkan bahwa nilai mean dua kabupaten berbeda. Nilai mean pada Kabupaten Tulungagung lebih besar dari Kabupaten Bangkalan. Pada variabel proporsi BBLR Kabupaten Tulungagung memiliki nilai $t$ hitung lebih besar dari nilai t hitung pada Kabupaten Bangkalan. Proporsi BBLR banyak ditemukan pada Kabupaten Tulungagung. Kabupaten Bangkalan memiliki nilai t hitung jauh lebih besar dari pada Kabupaten Tulungagung yaitu pada variabel rumah tangga non listrik dan rumah tangga tanpa air bersih. Proposi BBLR pada kedua kabupaten tersebut disebabkan oleh variabel rumah tangga tanpa arus listrik dan serta rumah tangga tanpa air bersih.

Tabel 1. Hasil Uji Regresi Linier Indikator Ketahanan Pangan Terhadap Proporsi BBLR

\begin{tabular}{lc}
\hline \multicolumn{1}{c}{ Variabel } & P value \\
\hline Rasio warung & 0,514 \\
Rasio toko & 0,979 \\
Non sejahtera & 0,435 \\
Non listrik & 0,226 \\
Akses roda 4 & 0,976 \\
Non sekolah & 0,211 \\
Non air bersih & 0,344 \\
Nakes & 0,941 \\
Sanitasi & 0,670 \\
\hline
\end{tabular}

Tabel 2. Hasil Uji t-test perbedaan pengaruh rawan pangan dengan proporsi BBLR di Kabupaten Bangkalan dan Kabupaten Tulungagung.

\begin{tabular}{|c|c|c|c|c|c|}
\hline \multirow{2}{*}{ Variabel } & \multicolumn{2}{|c|}{ Kabupaten Bangkalan } & \multicolumn{2}{|c|}{ Kabupaten Tulungagung } & \multirow{2}{*}{$P$ value } \\
\hline & Mean & SD & Mean & SD & \\
\hline Proporsi BBLR & 1,5250 & 0,7639 & 4,9810 & 5,4654 & 0,018 \\
\hline Rasiowarung & 0,0134 & 0,0096 & 0,0105 & 0,0049 & 0,006 \\
\hline Rasiotoko & 0,0258 & 0,0131 & 0,0370 & 0,0148 & 0,994 \\
\hline Non sejahtera & 0,3157 & 0,1610 & 0,1363 & 0,0853 & 0,019 \\
\hline Nonlistrik & 0,0055 & 0,0076 & 0,0013 & 0,0008 & 0,000 \\
\hline Aksesroda 4 & 1,0441 & 0,1066 & 1,0413 & 0,0896 & 0,954 \\
\hline Non sekolah & 0,0906 & 0,0253 & 0,0384 & 0,0168 & 0,084 \\
\hline Non air bersih & 0,1131 & 0,1237 & 0,0388 & 0,0343 & 0,001 \\
\hline Nakes & 0,0010 & 0,0004 & 0,0024 & 0,0035 & 0,137 \\
\hline Sanitasi & 0,0649 & 0,0587 & 0,0436 & 0,0614 & 0,959 \\
\hline
\end{tabular}


Variabel rumah tangga tanpa arus listrik menunjukan keterbatasan akses, akses yang susah menyebabkan distribusi makanan pada Kabupaten rendah apabila distribusi rendah menyebabkan ketersediaan pangan yang rendah $^{2}$. Pada variabel rumah tangga tanpa air bersih menyebabkan BBLR karena air bersih dapat menyebabkan terjadi infeksi pada ibu hamil. Faktor dari BBLR terdapat pada ibu yaitu status gizi, penyakit selama kehamilan serta infeksi selama kehamilan ${ }^{16}$.

Data yang diolah menunjukan nilai $\mathrm{t}$ hitung yang homogen yaitu pada rasio toko sebesar 0,994, rasio non sekolah sebesar 0,084 , rasio jumlah nakes sebesar 0,137 , rasio fasilitas sanitasi sebesar $0,959>\alpha, \alpha=0,05$. Uji Statistik menunjukan ada perbedaan pengaruh wilayah rawan pangan, variabel yang mempengaruhi yaitu rasio toko, rasio non sekolah, rasio jumlah nakes dan fasilitas sanitasi di Kabupaten Bangkalan dan Kabupaten Tulungagung Provoinsi Jawa Timur. Sedangkan pada nilai $\mathrm{t}$ hitung yang tidak homogen yaitu proporsi BBLR sebesar 0,018, rasio warung sebesar 0,006 , rasio non sejahtera sebesar 0,019 , rasio non listrik sebesar 0,000 dan rasio non air bersih sebesar $0,001<\alpha$, maka ho ditolak, yang artinya tidak ada perbedaan pengaruh dari indikator ketahanan pangan pada wilayah rawan pangan di Kabupaten Bangkalan dan Kabupaten Tulungagung. Indikator yang memiliki perbedaa pengaruh proposi BBLR pada kedua kabupaten yaitu rasio toko, rasio non sekolah, rasio jumlah nakes dan fasilitas sanitasi. Pada Kabupaten Bangkalan merupakan kabupaten dengan wilayah prioritas pembangunan, indikator rasio toko yang berpengaruh tinggi ada pada Kabupaten Bangkalan ${ }^{2}$. Rasio toko dapat menggambarkan ketersediaan pangan yang cukup untuk dikonsumsi suatu wilayah. Apabila ketersediaan pangan tidak terpenuhi maka makanan yang hendak dikonsumsi individu terutama ibu hamil rendah hal ini menyebabkan kejadian bayi lahir dengan berat badan rendah ${ }^{17}$. Indikator yang tidak memiliki perbedaan pengaruh ada pada indikator rasio warung, rasio non sejahtera, rasio non listrik, dan rasio non air bersih. Hal ini dikarenakan adanya kesamaan pada kedua
Kabupaten, kesamaan tersebut salah satunya adalah angka kemiskinan pada kedua Kabupaten tinggi ${ }^{4}$.

\section{KESIMPULAN}

Hasil analisis yang telah dilakukan menunjukkan bahwa tidak ada pengaruh indikator ketahanan pangan di Kabupaten Bangkalan dan Tulungagung terhadap proporsi BBLR. Namun hasil analisis menunjukkan bahwa ada perbedaan antara faktor yang berpengaruh pada wilayah rawan pangan (Kabupaten Bangkalan dan Kabupaten Tulungagung). Faktor pengaruh tersebut yaitu rasio toko, rasio anak tidak sekolah, rasio jumlah tenaga kesehatan, dan rasio fasilitas sanitasi. Namun faktor pengaruh yang tidak memiliki perbedaan pada kedua Kabupaten yaitu pada faktor proporsi BBLR, rasio warung, rasio rumah tangga tidak sejahtera, rasio akses roda 4, rasio rumah tangga tanpa arus listrik dan rasio rumah tangga tanpa air bersih. Hasil dari penelitian ini diharapkan dapat menjadikan bahan rujukan Dinas Ketahanan Pangan dan Dinas Kesehatan kedua Kabupaten serta sebagai pengawasan wilayah rentan akan angka kemiskinan, serta proporsi BBLR yang berkaitan dengan derajat kemiskinan.

\section{ACKNOWLEGMENT}

Penghargaan diberikan penulis kepada Dinas Pertanian dan Ketahanan Pangan Provinsi Jawa Timur, Dinas Kesehatan Kabupaten Bangkalan dan Kabupaten Tulungagung dan Fakultas Kesehatan Masyarakat Khususnya Departemen Gizi Universitas Airlangga.

\section{REFERENSI}

1. Subagio, A. Modified cassava flour (MOCAL) sebagai ketahanan pangan nasional berbasis potensi lokal. J. Teknol. Dan Kejuru. 14, 92-103 (2008).

2. Dinas Pertanian dan Ketahanan Pangan. Peta Ketahanan dan Kerentanan Pangan Tingkat Desa Provinsi Jawa Timur. (2016).

3. Mun'im, A. Analisis Pengaruh Faktor 
Ketersediaan, Akses, Dan Penyerapan Pangan Terhadap Ketahanan Pangan Di Kabupaten Surplus Pangan: Pendekatan Partial Least Square Path Modeling. J. Agro Ekon. 30, 41-58 (2012).

4. Badan Pusat Statistik. Berita Resmi Statistik: Profil Kemiskinan di Jawa Timur September 2016. (2017).

5. Dinas Perikanan dan Kelautan Provinsi Jawa Timur. Statistik Perikanan Provinsi Jawa Timur tahun 2013. (2013).

6. Romadhon, A. \& Sucipto. Pemetaan Potensi Komoditas dan Rancangan Pengembangan Di Kecamatan Blega, Bangkalan Madura. Agrovigor 3, 146-156 (2010).

7. Suhartono. Indikator dan Pemetaan Daerah Rawan Pangan Dalam Mendeteksi Kerawanan Pangan di Kecamatan Tanjung Bumi Kabupaten Bangkalan. Bangkalan. EMBRYO 7, (2010).

8. Hapsari, N. I. \& Rudiarto, I. Faktor-Faktor yang Mempengaruhi Kerawanan dan Ketahanan Pangan dan Implikasi Kebijakannya di Kabupaten Rembang. J. Wil. dan Lingkung. 5, 125 (2017).

9. Dinas Kesehatan Bangkalan. Profil Kesehatan Kabupaten Bangkalan. (2015).

10. Dinas Kesehatan Tulungagung. Profil Kesehatan Kabupaten Tulungagung. (2015).

11. Suryati. Faktor-Faktor Yang Mempengaruhi Kejadian Bblr DI Wilayah Kerja Puskesmas Air Dingin Tahun 2013. J. Kesehat. Masy. Andalas 8, 72-78 (2014).
12. Diniyah Nashihatu, Rahayu Atikah, M. Faktor Risiko Yang Berhubungan Dengan Berat Badan Bayi Lahir rendah Wilayah Kerja Puskesmas Martapura Kabupaten Banjar. J. Publ. Kesehat. Masy. Indones. 3, 100-105 (2016).

13. Damanik, R. Kejadian Bayi Berat Lahir Rendah Dan Faktor-Faktor Yang Mempengaruhinya. (2011).

14. Anita, S. Pengaruh Status Sosial ekonomi, budaya, dan pemeriksaan kehamilan Terhadap Kejadian Bayi Berat Lahir Rendah (BBLR) di Wilayah Kerja Puskesmas Pancur Batu Kabupaten Deli Serdang Tahun 2012. J. Kesehat. Masy. dan Lingkung. Hidup 1, 1-6 (2014).

15. Nuryani, N. \& Rahmawati, R. Kejadian Berat Badan Lahir Rendah di Desa Tinelo Kabupaten Gorontalo dan Faktor yang Memengaruhinya. J. Gizi dan Pangan 12, 49-54 (2017).

16. Prisusanti, R. D. PATH ANALYSIS FAKTORFAKTOR YANG BERHUBUNGAN DENGAN KEJADIAN BAYI BERAT BADAN LAHIR RENDAH DI RSUD BANGIL KABUPATEN PASURUAN JAWA TIMUR. Wijaya Kusuma Malang J. 1, 23-31 (2017).

17. Budiman, Riyanto Agus, Juhaeriah Juju, $\mathrm{H}$. G. Faktor Ibu yang Berhubungan dengan Berat Badan Bayi Lahir di Puskesmas Garuda Tahun 2010. J. Kesehat. Kartika 1-12 (2010). 